\title{
Actoren in het enquêterecht
}

\author{
Mr.drs. A.A. Bootsma en mr. dr. E.A. van Dooren*
}

\begin{abstract}
Deze bijdrage biedt een introductie op het themanummer 'actoren in het enquêterecht' ter gelegenheid van het vijftigjarig bestaan van de Ondernemingskamer. Het nummer bevat bijdragen over raden, de raadsheer-commissaris, onderzoekers, tijdelijke bestuurders en commissarissen, tijdelijke beheerders van aandelen en belanghebbenden. Het nummer opent met een column van de voorzitter van de Ondernemingskamer en wordt afgesloten met een praktijkbijdrage van een OK-functionaris.
\end{abstract}

Het is dit jaar precies vijftig jaar geleden dat de Ondernemingskamer bij het gerechtshof te Amsterdam werd ingesteld. ${ }^{1}$ Veel verjaardagen, lustrumvieringen en andere jubilea gaan in deze coronatijd min of meer onopgemerkt voorbij, maar dat geldt gelukkig niet voor deze mijlpaal. ${ }^{2}$ De redactie van het Maandblad voor Ondernemingsrecht heeft deze gelegenheid aangegrepen voor een themanummer over het enquêterecht, dat nog altijd de core business van de Ondernemingskamer is. ${ }^{3}$ In dit themanummer worden enkele actoren in het enquêterecht belicht. Dat zijn immers de mensen die het instituut maken tot wat het nu al een halve eeuw is.

Het nummer opent met een column van Gijs Makkink. Hij belichaamt als voorzitter van de Ondernemingskamer het perspectief van de raadsheer. Per 1 september 2021 neemt hij afscheid als voorzitter van de Ondernemingskamer en zal hij het (enquête)recht als raadsheer in de civiele kamer van de Hoge Raad 'van boven' gaan bezien. ${ }^{4}$ In een column over de actuele discussie over de plaats van de onderneming in de samenleving en van de samenleving in de onderneming komt zijn (enquête)rechtoverstijgende blik tot uiting. Makkink ziet een mogelijke rol voor het enquêterecht weggelegd om de hui-

Mr. drs. A.A. Bootsma is werkzaam bij het wetenschappelijk bureau van de Hoge Raad der Nederlanden en lid van de redactie van dit tijdschrift. Mr. dr. E.A. van Dooren is universitair docent bij het Molengraaff Instituut voor Privaatrecht van de Universiteit Utrecht en lid van de redactie van dit tijdschrift.

Mr. drs. A.A. Bootsma schrijft op persoonlijke titel.

1. Art. 41 van de wet van 10 september 1970, Stb. 1970, 411, in werking getreden op 1 januari 1971.

2. Vgl. naar aanleiding van eerdere mijlpalen bijv. W.J. Slagter e.a., 25 jaar Ondernemingskamer: de betekenis van de OK voor ondernemend Nederland, Den Haag: Sdu 1996 en H.J. Smit, Na 30 jaar enquêterechtspraak van de Ondernemingskamer, Ondernemingsrecht 2002, p. 42.

3. Zie bijv. L. Timmerman, Het Nederlandse vennootschapsrecht tussen 1918 en 2018, enkele schetsmatige opmerkingen, in: H.J. de Kluiver (red.), 100 jaar Handelsrecht. Over heden, toekomst en verleden (Jubileumuitgave Vereeniging 'Handelsrecht' 1918-2018), Zutphen: Paris 2018, p. 82.

4. Vgl. C.W.M. van Ballegooijen \& P. Ingelse (red.), Het Hof van boven (Prinsengrachtreeks), Nijmegen: Ars Aequi Libri 2002. dige opvattingen over de maatschappelijke verantwoordelijkheid van ondernemingen in het ondernemingsrecht gestalte te geven.

De Ondernemingskamer wordt gekenmerkt door haar bijzondere samenstelling in vergelijking met andere rechterlijke instanties. De Ondernemingskamer bestaat naast drie raadsheren uit twee deskundige leden, de zogenoemde raden. ${ }^{5}$ In de bijdrage van Maarten Hendriks, Sophie Prins en Steven ten Have wordt de rol van deze raden in de Ondernemingskamer belicht. De auteurs - respectievelijk organisatieadviseur, secretaris van de Ondernemingskamer en onder andere raad in de Ondernemingskamer - doen dat op multidisciplinaire wijze. Naast literatuuronderzoek hebben zij in hun bijdrage gebruikgemaakt van de uitkomsten van vragenlijsten, die door zestien raden zijn ingevuld, en van twee interviews die zijn gehouden met de voorzitter van de Ondernemingskamer en een raadsheer die betrokken is bij de selectie van de raden. De auteurs constateren dat relatief weinig bekend is over de raden en hun rol binnen de Ondernemingskamer. De bijdrage biedt een interessante inkijk in de toegevoegde waarde van de raden, zowel bij de (voorbereiding van de) zitting als bij het 'raadkameren'.

Ten opzichte van het vijftigjarig bestaan van de Ondernemingskamer - en de historie van het enquêterecht, die nog veel langer teruggaat ${ }^{6}$ - heeft betrekkelijk recent, in 2013, de raadsheer-commissaris zijn intrede in het enquêterecht gedaan. ${ }^{7}$ De raadsheer-commissaris heeft inmiddels een vaste plaats verworven en staat centraal in de bijdrage van de hand van de advocaten Ellen Soerjatin en Coco Kruse. Zij geven een overzicht van de taken en verplichtingen van de raadsheercommissaris en beschrijven hoe deze rol in de praktijk wordt uitgeoefend. Daarbij gaan zij onder meer in op enkele in het oog springende beslissingen van de raadsheer-commissaris en geven zij een overzicht van suggesties tot verdere uitbreiding van de rol van de raadsheer-commissaris.

5. Zie art. 66 lid 2 Wet RO

6. Zie over die geschiedenis bijv. P.J. Dortmond, Het beruchte recht van enquête (van 1910 tot 1928), in: K.M. van Hassel \& M.P. Nieuwe Weme (red.), Willems' wegen (VDHI nr. 102), Deventer: Kluwer 2010, p. 91-96 en J.M. de Jongh, Over het Britse enquêterecht en palmen aan de oever van het IJ, in: G.C. Makkink e.a. (red.), Ik ben niet overtuigd (Ingelse-bundel), Nijmegen: Ars Aequi Libri 2015, p. 247-254.

7. Wet van 18 juni 2012, Stb. 2012, 274, in werking getreden op 1 januari 2013. 


\section{Maandblad}

Ondernemingsrecht

Van oudsher vormt het onderzoek de kern van het in de wet neergelegde stelsel van het enquêterecht. ${ }^{8}$ De onderzoeker speelt dan ook een centrale rol in het enqueterecht. Camiel Hanegraaf, die werkzaam is als advocaat, behandelt de positie van de onderzoeker aan de hand van de Leidraad voor onderzoekers in enquêteprocedures, vastgesteld door de Ondernemingskamer op 9 juli $2019 .{ }^{9}$

Er wordt intussen wel geschreven dat het onderzoek niet langer de enige kern van het in de wet neergelegde stelsel van het enquêterecht vormt. ${ }^{10}$ Met de invoering van artikel 2:349a BW in 1994 heeft de Ondernemingskamer de mogelijkheid gekregen onmiddellijke voorzieningen te treffen. ${ }^{11}$ De meest voorkomende onmiddellijke voorzieningen zijn die waarbij de Ondernemingskamer tijdelijke bestuurders, commissarissen of beheerders van aandelen benoemt.

In de bijdrage van Dirk-Jan Duynstee en Tiemen Drenth wordt ingegaan op de positie van tijdelijke bestuurders en commissarissen. Beiden zijn advocaat en constateren dat door de Ondernemingskamer benoemde bestuurders (en commissarissen) opereren onder moeilijke omstandigheden, waarin zij in toenemende mate aansprakelijk worden gesteld en soms zelfs worden geconfronteerd met intimidatie en bedreiging. De aansprakelijkheid van door de Ondernemingskamer benoemde bestuurders moet worden beoordeeld aan de hand van de bekende ernstigverwijtmaatstaf, waarbij er ruimte bestaat om alle omstandigheden van het geval waarin bestuurders opereren mee te wegen. Duynstee en Drenth vinden het begrijpelijk dat de Ondernemingskamer zoekt naar middelen om de door haar benoemde bestuurders en commissarissen waar mogelijk te beschermen, maar zij plaatsen vraagtekens bij enkele van de daarbij gehanteerde middelen. $\mathrm{Zij}$ houden ten slotte een pleidooi voor beter toezicht op door de Ondernemingskamer benoemde functionarissen, waarbij zij onder meer een grotere rol zien weggelegd voor de raadsheercommissaris.

De tijdelijke beheerder van aandelen staat centraal in de bijdrage van Erik van Emden en Juliette Wareman. Zij hebben gezamenlijk een boek ${ }^{12}$ over deze sui generis-figuur ${ }^{13}$ gepubliceerd. In hun bijdrage geven zij onder meer hun visie op enkele nog niet uitgekristalliseerde vraagstukken ten aanzien van

8. HR 27 september 2000, ECLI:NL:HR:2000:AA7245, NJ 2000/653, r.o. 4.2.

9. Gepubliceerd op de website van de Ondernemingskamer, www.rechtspraak.nl/SiteCollectionDocuments/leidraad-vooronderzoekers-in-enqueteprocedures.pdf.

10. Zie bijv. M.W. Josephus Jitta, Tijd voor wijziging van het paradigma, Ondernemingsrecht 2018/69.

11. Wet van 8 november 1993, Stb. 1993, 597, in werking getreden op 1 januari 1994. Art. 2:349a BW is per 1 januari 2013 gewijzigd (zie noot 7).

12. E.L.A. van Emden \& J. Wareman, De door de Ondernemingskamer benoemde tijdelijk beheerder van aandelen (Prinsengrachtreeks), Nijmegen: Ars Aequi Libri 2020, besproken door K. Rutten in MvO 2021, afl. 5-6, 166-170

13. Hof Amsterdam (OK) 30 april 2019, ECLI:NL:GHAMS:2019:1535, JOR 2019/187. het beheer van aandelen, waaronder de zekerheidstelling ten behoeve van de beheerder van aandelen, de verkoop van materiële activa van de vennootschap waarvan de beheerder de aandelen in beheer heeft, en het ontslag van bestuurders door de beheerder van aandelen.

In een tweede bijdrage van de hand van Hanegraaf wordt ingegaan op de positie van de belanghebbende in het enquêterecht. Hij concludeert aan de hand van wetgeving en jurisprudentie dat in de praktijk niet altijd duidelijk is wie kwalificeert als belanghebbende en doet enkele aanbevelingen voor verbeteringen, waaronder een 'Leidraad voor belanghebbenden in enquêteprocedures'.

Dit nummer wordt afgesloten met een praktijkbijdrage van de hand van Willem van Hassel. Hij is oud-advocaat en heeft veelvuldig opgetreden als door de Ondernemingskamer benoemde functionaris. Een aantal memorabele enquêteprocedures passeert de revue, waarna hij enkele kanttekeningen plaatst bij de huidige enquêteprocedure en praktische aanbevelingen doet.

Daarmee zijn we weer terug bij het begin. Zoals Makkink in zijn openingscolumn concludeert, staat het recht gelukkig nooit stil. Vele observaties, aanbevelingen en suggesties uit dit themanummer zullen ongetwijfeld vroeg of laat de weg naar de praktijk van het enquêterecht weten te vinden. De redactie dankt alle auteurs voor hun bijdragen aan dit themanummer. Daarnaast is een bijzonder woord van dank aan de Ondernemingskamer op zijn plaats voor haar medewerking aan het artikel over de raden. Op naar het volgende jubileum! 